\title{
Innovating a system for producing and distributing hybrid oil palm seedlings to smallholder farmers in Benin
}

\author{
Pierre V. Vissoh ${ }^{1, *}$, Rigobert C. Tossou ${ }^{1}$, Essegbemon Akpo ${ }^{1}$, Dansou Kossou ${ }^{1}$ and Janice Jiggins ${ }^{2}$ \\ ${ }^{1}$ Faculté des sciences agronomiques, Université d'Abomey-Calavi, BP 526, FSA/UAC, Cotonou, Benin \\ ${ }^{2}$ Knowledge, Technology and Innovation Group, Wageningen University, Hollandseweg 1, Wageningen, KN 6706, The Netherlands
}

\begin{abstract}
This article analyses the development of a system for producing and distributing hybrid oil palm seedlings to small-scale famers. The existing seed system had become so corrupted that the seedlings actually planted were largely of unimproved kinds. The article describes institutional experiments carried out by two Innovation Platforms (IPs) in order to improve the oil palm seed system. Theory Guided Process Inquiry was used to document, evaluate and analyse these interventions. The experiments catalysed changes in interpersonal and inter-organisational power relationships that enabled further co-learning and co-construction of understanding and action among key stakeholders in the oil palm domain. The IPs and those who became local champions of seed system innovation, also triggered change in institutional behaviours, technologies, and practices that further improved the integrity of the seed system. Official nursery holders must now be trained, registered and licensed by local government. Farmers are encouraged to source hybrid seedlings only from licensed nurseries. These achievements were then shared and discussed with officials and higher level government leaders, drawing on IP members' pre-existing professional and personal networks. Improvement of the oil palm seed system was included in the government's latest 5-year development plan.
\end{abstract}

Keywords: institutional development / stakeholders / innovation / seedling system / oil palm / Benin

Résumé - Systèmes d'innovation pour la production et la distribution de plants améliorés de palmier à huile aux petits producteurs du Bénin. Cet article analyse le développement d'un système de production et de distribution de plants améliorés de palmier à huile aux petits producteurs. Le système semencier actuel est si corrompu que les plants fournis sont de mauvaise qualité. Cet article décrit des expérimentations institutionnelles à l'aide de deux plate-formes d'innovation afin d'améliorer le système semencier du palmier à huile. Un processus d'enquêtes a été utilisé pour documenter, évaluer et analyser ces interventions. Les expérimentations institutionnelles ont induit divers changements dans les relations de pouvoir interpersonnel et inter-organisationnel, facilitant un apprentissage mutuel et une co-construction entre les acteurs de la filière palmier à huile. Les plate-formes d'innovation ont entraîné un changement institutionnel dans les habitudes, les technologies et les pratiques, qui ont en outre amélioré la probité du système semencier. Les pépiniéristes doivent à présent être formés, enregistrés et autorisés par les communes. Ces acquis ont ensuite été discutés avec les décideurs politiques locaux et nationaux en utilisant les réseaux des membres des plate-formes d'innovation. L'amélioration du système semencier du palmier à huile a ainsi été incluse dans le dernier plan de développement quinquennal du gouvernement.

Mots clés : renforcement institutionnel / innovation / exploitation agricole / système semencier / palmier à huile / Bénin

\section{Introduction}

This article evaluates the role of multi-stakeholder innovation platforms (IPs) located in the 'communes' of Sakété ('Département Plateau') and Klouécanmè ('Département Couffo') in the heart of the Benin's oil palm production

\footnotetext{
* Corresponding author: pierrevissoh@yahoo.fr
}

zone. It is based on three years action research on the role of the IPs in generating institutional change to secure the integrity of the hybrid oil palm seedling supply chain. The main research questions were: to what extent can the effects observed be attributed to the intervention of the IPs? If so, how did the IPs achieve these effects?

The concept of innovation platform is increasingly used in interventions inspired by agricultural innovation system thinking, as a way of bringing together stakeholders from a sector 
to enable transformative change (Klerkx et al., 2013; van Paassen et al., 2013). An IP is defined as 'a space for learning and change. It is a group of individuals (who often represent organisations) with different backgrounds and interests: farmers, traders, food processors, researchers, government officials, etc. The members come together to diagnose problems, identify opportunities and find ways to achieve their goals. They design and implement activities as a platform or coordinate activities by individual members' (Homann-Kee Tui et al., 2013).

The Benin government has attempted to revitalise the oil palm sector because of its multi-functional role as food supplier, employment generator and cash provider. The domestic industry is split between a handful of inefficient commercial plantations and processing factories supplied by their own out-growers and a mass of smallholder producers. Benin currently imports about $40 \%$ of its crude palm oil (CPO) requirements (Vissoh et al., 2010).

An initial diagnostic study (Akpo et al., 2012) revealed that the existing oil palm seed system had led to a reduction in the proportion of hybrid seedlings planted, chiefly because nonauthorised nurseries were selling unimproved or wild seedlings; authorised nurseries were poorly accessible due to their geographical distribution; hybrid planting material was scarce and expensive, and seedlings were poorly cared for in the nurseries. Since it is impossible to detect seedling quality or type by visual inspection, corrupt practices were rife. Following scoping studies, research locations were selected at the end 2010. Two IPs were constituted as multi-stakeholder groups whose members were selected mainly at the commune level; later, they also built relationships with national actors. Multi-stakeholder platforms/groups are known as processes that bring together the main stakeholders to address an issue and to reach collective outcomes (GIZ, 2011). Through multistakeholder processes, different players collaborate, learn from each other and share knowledge (Triomphe et al., 2013). A part-time scientist Research Associate (RA), with a PhD in weed science and sociology, facilitated the IPs' and monitored the research processes.

The study was part of the Convergence of Sciences Strengthening Innovation Systems programme (CoS-SIS) (Hounkonnou et al., 2012). The programme's basic assumption was that both technical and institutional development must be addressed if smallholders are to capture opportunities. The work reported here focused on institutional change to create enabling conditions for smallholder entrepreneurship. The IPs were expected to be instrumental in mobilising key actors to interact in support of smallholder innovation and to learn how to explore changes of common interest (Hounkonnou et al., 2012; Spielman et al., 2009). In early 2011, the IPs defined the following entry points: informing farmers on the potential of hybrid palms, improving interaction among nursery holders, farmers, extension services and the research centre CRA-PP (Centre de Recherches Agricoles-Plantes Pérennes) at Pobè, supported by INRAB (Institut de Recherches Agricoles du Bénin), and developing the coverage and integrity of the seedling supply chain.

\section{Methodology}

The research design had two strands. The IPs' main approach to opening space for innovation was based on iterative cycles of action researching. At the same time, Theory Guided Process Inquiry (TGPI) protocols (Faletti, 2006; George and Bennett, 2005) were used to record a standard set of data, analysed in a peer review process during regional workshops approximately every four months over the entire study period. TGPI is a robust technique for testing theories of causality-inaction by examining the intervening steps and events. It attempts to identify the causal processes and mechanisms linking a potential cause (e.g., an intervention) and an effect or outcome (e.g., changes in local government practice). Two explanatory causal hypotheses were adopted at the start of the study:

- that the interventions by the IPs caused the effects documented; and

- that pre-existing and newly formed configurations of power within and external to the IPs offered the best explanation of the effects observed (Jiggins et al., 2016).

In terms of the intervention hypothesis, the IPs formulated the following causal statements with respect to their interventions:

- change in technical practices requires institutional innovation;

- change in inter-organisational arrangements among the key actors creates space for innovation; and

- the IPs facilitate change in actor relationships.

In terms of the power hypothesis, the IPs' considered in particular the role of 'innovation champions' i.e. 'individuals who informally emerge in an organization and make a decisive contribution to the innovation by actively and enthusiastically promoting its progress through the critical stages' (Klerkx and Aarts, 2013). Such champions seek to remove any barriers that emerge in an innovation process, such as insufficient resources, missing inter-organisational links, poor collaboration between actors or opposition of incumbent actors.

\section{Data collection and analysis}

The regional workshop began by identifying existing institutions that blocked opportunities for smallholders in the seedling supply system and by brainstorming the kinds of changes needed to unblock them, how these might be brought about and who could take the necessary actions. Drawing on the institutional studies of Avelino and Rotmans (2009) and Fuchs and Graab (2011), IPs' members then prioritised and planned activities for changing the following features of the existing situation: official and informal rules, norms, material structures and practices, relationships, understanding of how the supply system works/should work.

During the initial period the RA also began sketching the structure of linkages among the IP members and other key actors in the seedling supply chain. These diagrams (Fig. 1) were validated with IP members and periodically updated to capture changes in inter-organisational and inter-personal linkages. As the IPs began to function, information on key events in the domain, the activities and decisions of the IPs, the RA's observations on these, and the immediate effects, were documented, reported and analysed against the two TGPI hypotheses, at each regional workshop. The RA also maintained a facilitation diary throughout, noting how he 


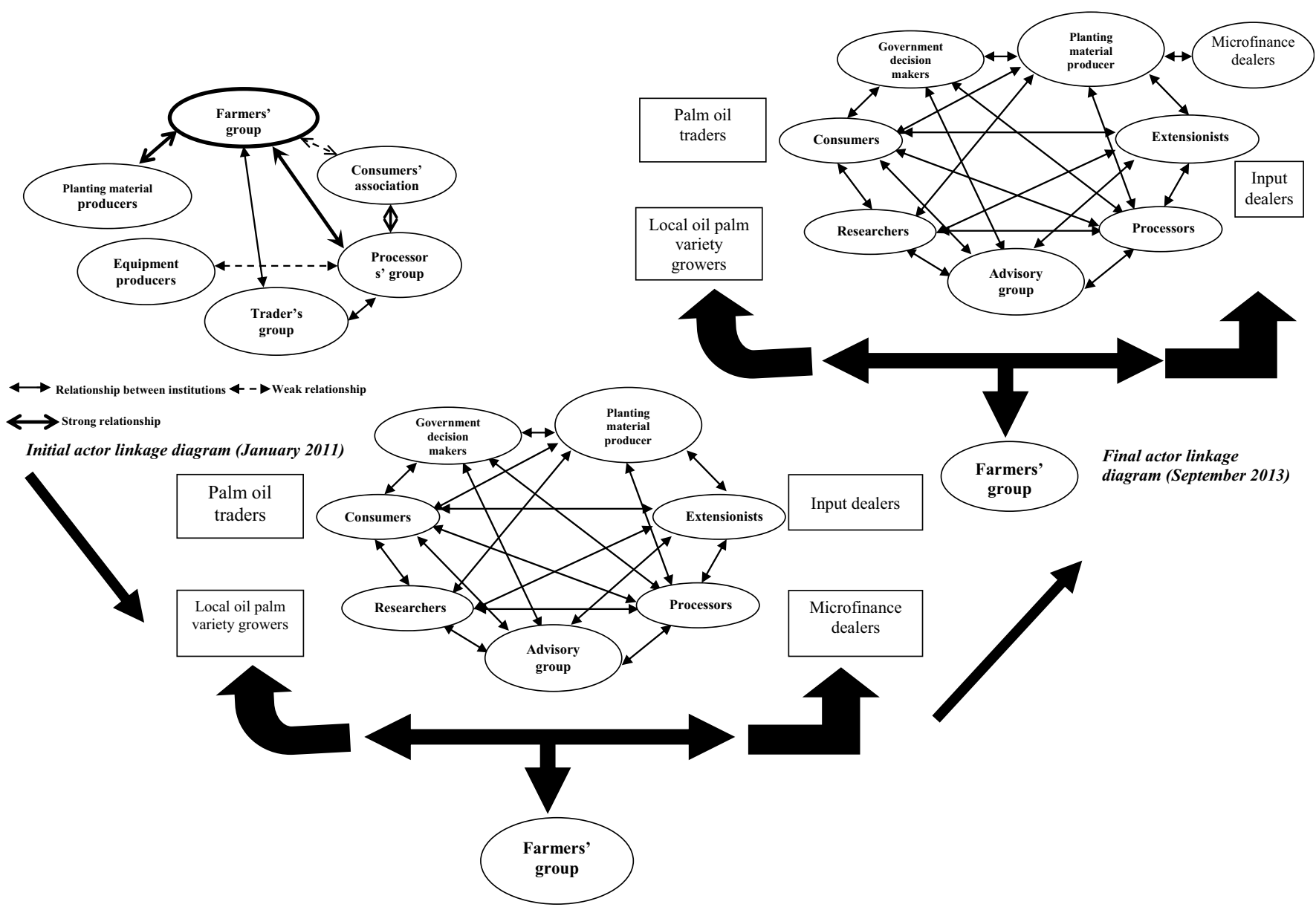

Fig. 1. Actor relations at three different points in time.

Fig. 1. Relations entre acteurs à différentes périodes du processus.

interacted with the IP members and supported their work. Nederlof and Pyburn (2012) documented and analysed the RAs' facilitation experiences and their effects. A narrative 'rich description' of the IP and its context for the period, and written reports by the National and Regional Programme Coordinators of events in the domain and in the national or larger context and of the actions taken by themselves and by members of the national Programme Management Team (PMT), complemented the evidential material.

In early 2012, for each IP, special studies were initiated on the role of champions, IP dynamics, external influences on the IP's work and the role of the National Programme Coordinator and the Programme Management Team. At regional workshops during the latter half of 2013, all this material for the eight domains in three participating countries (i.e. water management, oil palm and cotton in Benin; Oil palm and cocoa in Ghana and crops and livestock, water management and shea in Mali) were drawn together, analysed and tested against the two declared explanatory theories and the sub-hypotheses formulated by each IP.

\section{Key findings and analysis}

First results confirmed that it is impossible to identify the type and quality of a seedling by visual inspection, that mislabelling of seedlings (to obtain the higher price commanded by hybrids) was common practice (Akpo et al., 2014a) and that it was the more recent plantings of oil palm that contained the higher percentage of unimproved (including sterile) trees. The $\mathrm{PhD}$ student also analysed the seedling distribution system to identify in more detail the sociotechnical, biological and agronomic shortcomings in the seed system (Akpo et al., 2012).

The IP members included individuals from a farmer-based organisation, individual smallholder farmers, researchers, extensionists, oil palm scientists, and the RA. During a meeting with commune officials they negotiated and designed an action-research plan to improve the oil palm seed system as an experiment hoping that, if successful, it might work also in other parts of Benin. The main actions were directed towards the supply of improved planting material to smallholders directly from the research centre and to regulate seedling supply.

Agronomic and nursery management experiments and social learning activities, were carried out with official nursery holders and key stakeholders identified in the actor linkage diagrams (Fig. 1). They evaluated together the effectiveness of the adaptations that nursery holders had made to meet research recommendations' package in order to produce reliable and high quality seedlings in the actual conditions of their nurseries 
Table 1. Power analysis: supply of certified planting material and licensing.

Tableau 1. Analyse des relations de pouvoir pour la fourniture de matériel végétal certifié. Situation initiale (2012) et situation après intervention de la plate-forme d'innovation (2013).

The initial situation (2012)

Power over

Researchers: developing and selling hybrid seedlings and responsible for certifying seedling quality

Power with

Extension agents (supporting or corrupting the seed system, together with unauthorised nurseries, and farmers seeking cheap seedlings)

\section{Power to}

Nursery holders: serving small farmers but not well spread through the production zone \& with opportunities for cheating customers; can choose to become licensed

Extension agents: can corrupt the system by encouraging or ignoring sales of inferior material

Power within

The situation following actions taken by IP members (2013)

Power over

CRA-PP researcher: monitors nursery practices; confers or withdraws annual certificate of authorised nurseries, certifies seedling quality CRA-PP: licensing authority, ensures supply of certified seedlings, develops best practices

\section{Power with}

Extension agents: under pressure from CBOs, FBOs and NGOs comply with the new norms for best practice and work with IPs to support integrity of the new seed system

IP members: act with other stakeholders to introduce and monitor the licensing system

\section{Power to}

IPs: transform the situation

Micro-finance organisations and input dealers: promote and extend good practices

Nursery holders: choose to become licensed, influence the seedling market

FBOs: encourage farmers to buy only from licensed nurseries Power within

Champions within and outside IP: raise awareness of importance of maintaining the integrity of the seed system

FBO: farmer based organisation; CBO: consumer based organisation; NGO: non-governmental organisation.

Source: IP members' analyses of TGPI data.

(Akpo et al., 2014b, 2014c). This process of co-producing knowledge enabled nursery holders to learn new practices from each other and from the researchers and extension agents, and for the researchers, extension agents and local officials to better appreciate the conditions facing nursery holders (Akpo et al., 2014d). At the same time, during workshops and field visits, farmers in the two study areas were sensitised to the advantages of hybrid oil planting material. The research centre became responsible for directly supplying all authorised nurseries with improved seedlings and increased its supply to enable the nurseries to meet increased demand. The IP selected five experienced oil palm farmers with some education and sufficient land in the areas where nursery coverage was poor, to establish new nurseries. They were trained in best nursery practices at the research centre and were certified as authorised nurserymen. The training included use of an appropriate bag size and type of substrate, as well as the amount and type of fertiliser needed to produce high quality planting material at a cost that allowed a reasonable profit for nursery holders and a fair price for farmers. Each of the newly trained nurserymen was given 2,500 pre-germinated oil palm seeds on credit to establish their nurseries. One of them subsequently purchased 7,500 additional seeds by taking a loan from a micro-finance organisation. For the first time this organisation was willing to make the loan to a smallholder because of the improvements in practices, management training and assured seedling quality.
The RA assisted IP members to analyse TGPI data to reveal changes over time in power relations brought about by these activities (Tab. 1). Successive analyses show the research centre has become the sole agency responsible for the training and annual certification of authorised nursery holders. Since the research centre can withdraw a certificate if a nursery holder deviates from the best practice, it has acquired power over certification and licensing. Licensed nursery holders are now entitled to legitimately claim that they sell true hybrids and charge the concomitant price. The municipal extension agency has power either to promote good practice or to corrupt the emergent seed system by recommending non-authorised suppliers. Farmers still complain about the low quality of seedlings purchased from the remaining unauthorised nurseries. Therefore, the IPs now monitor nursery holders' practices as closely as possible. It appears to have met with considerable success in driving the worst offenders out of business.

A number of 'champions of change' emerged during this process and were supported by the IPs to use their professional and personal networks of influence to further open the space for institutional change (Klerkx et al., 2013). The three most important champions (Tab. 2) were identified by IP members as:

- a technology champion, an oil palm breeder, involved since the start of the IP. Initially responsible for the training, certification and selection of new sites, he now controls the 
Table 2. The role of champions.

Tableau 2. Rôle des « champions».

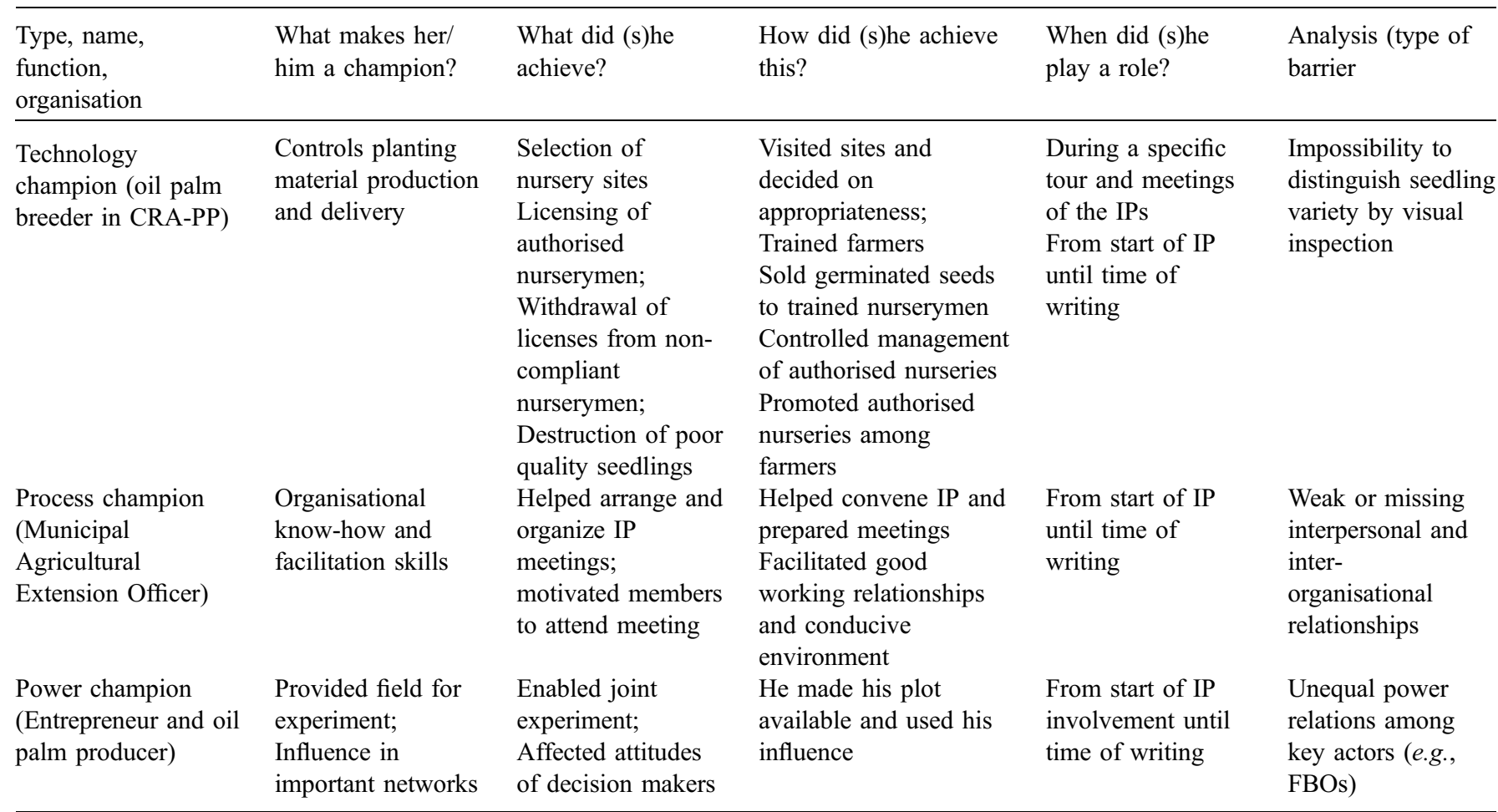

CRA-PP: Centre de recherches agricoles-plantes pérennes; FBO: farmers based organisation.

Source: RA's analysis of TGPI data; Klerkx et al. (2013).

production and distribution of improved planting material. He has acquired the power to sanction deviant nursery holders by destroying seedlings of poor quality and withdrawing certification;

- a process champion, a municipal agricultural extensionist, who emerged during the exploratory and diagnostic studies as skilled in facilitating meetings and creating a favourable and conducive learning environment;

- a power champion, who emerged from within the IP who is a private entrepreneur and successful oil palm grower with an influential social network he made facilities available for carrying out technical and institutional experiments and smoothed the path for meetings with (local) government agencies and officials.

The TGPI data also revealed a change in actor relationship, plotted on actor linkage diagrams (Fig. 1). At the start of the IPs' work, the strongest links were between smallholders, processors and nurserymen. Over time links began to be made or strengthened among a wider set of actors that included farmer-based organisations, equipment producers, traders, commune officers, oil palm researchers, extension agents, micro-finance organisations and consumers. As the IPs' activities evolved, the actors began to realise what each had 'at stake' and that satisfying their own interests depended on the others. By September 2013 the micro-finance organisation and an input dealer had become IP members. This proved important because by this time, the supply of improved seedlings could not meet the demand. The research centre had not taken into account the S-shape of the diffusion curve of hybrid seedlings. For instance, in the Commune of Zè, département Atlantique, demand had risen to about 30,000 seedlings. The two trained nurserymen of this commune had only received 5,000 pre-germinated hybrid seeds from the research centre. One of the two obtained a loan from a microfinance organisation to buy an additional 7,500. The IP decided to involve other micro-finance organizations to enable more of the licensed nursery holders to get such loans. Similarly, input dealers became associated with the IP to enable both nursery holders and oil palm growers to access the fertilizers recommended for seedlings in the nurseries and for hybrid palm plantations. It is worth noting that a number of the IP members are themselves palm traders and growers. From 2013 onwards the research centre has provided all licensed nursery holders with pre-germinated seeds on credit, in coordination with the micro-finance organisations.

From mid-2013 onwards, the IP members, commune leaders and the CoS-SIS national programme team (composed of domain champions with positions of influence in university, business and official networks) held a series of informal meetings with senior civil servants and members of government. The purpose was to present and discuss the research findings and effects of the actions taken in the study sites. The message that an efficient and effective seedling system was a sine qua non if the smallholder oil palm sector was to improve its productivity had a powerful impact. The role of the IPs in 
finding pathways forward also impressed the participants, because it proved that a relatively low cost intervention could generate responsibility for action among those who had most to lose by the corrupt seed system and most to gain if a robust and transparent system could be put in place. IPs thus influenced the five-year Agricultural Development Plan launched in 2014. For the first time it included a section dealing with the oil palm seed system, indicating that investments would be made over the plan period to roll out the institutional innovations developed by the IPs at the study sites.

\section{Discussion}

By the end of 2013, actors linked in the seedling system had become to a far greater extent mutually accountable for the system's integrity and aware of the benefits to themselves and the oil palm domain as a whole of using only certified, productive planting material. By learning how to act in concert they together have improved the seed system, and thereby the productivity and incomes of smallholder growers and other domain actors. Non-compliant suppliers of non-hybrid planting material are being pushed out of the market.

In terms of the institutional elements the IPs set out to change, the analyses above suggest the following:

- by working to change rules and norms the IPs have legitimated the importance of an honest and transparent seedling supply system;

- by providing training, best practices, quality seedlings, incentives and sanctions the IPs have changed material structures;

- by changing relationships the IPs have instituted new capabilities for shared sense-making and co-learning.

These changes support the hypothesis that it is the interventions of the IPs that have been co-causal in the effects observed.

Turning to questions of power, the analyses suggest the following.

\subsection{Change in technical practices requires institutional innovation}

It has been shown how the IPs interrupted the corrupt power relations that perverted the desire of smallholders to upgrade their plantations with higher yielding hybrid planting material, namely by introducing co-learning experiments, certification, licensing and other new 'rules of the game', and ways of enforcing them. At first, the production of germinated seeds of hybrid oil palms, growing seedlings in nurseries and distributing them to farmers were matters that IP members saw as a purely technical and logistic challenge. As their action researching activities proceeded, they discovered the institutional dimensions of these components of the supply system. Further, they began to understand why 'integrity' is such a crucial matter in seedling supply. Akpo et al. (2014a) had demonstrated that smallholders would discover only after five years, when the palms were supposed to start bearing fruit, whether or not they had wasted their money. The key actors learned that 'taking assurances on trust' was not at all the same thing as 'creating a trustworthy system'.

\subsection{Changes in organisational arrangements create spaces for innovation}

The IPs' main achievement in this respect was the introduction by the communes of a certification and licensing requirement, under the authority of the research centre and co-managed by licensed nursery holders. The subsequent willingness of micro-finance organisations to extend credit to smallholders for quality seedling purchases augmented the organisational impact.

\subsection{IPs are needed to catalyse changes in actor relationships}

The analyses indicate that not only the structure of actor relationships changed but also the quality of the relationships as the result of their activities. Power to maintain the integrity of the supply system became more connected and more widely distributed, with the majority of actors realising direct benefits. The power to corrupt seedling supply and mis-represented seedling quality was greatly reduced and closely monitored (Tab. 3). However, we also note the importance of the largely pre-existing networks of influence of the 'champions of change' (Tab. 2).

Rowlands (1997) suggests two ways in which change in power relations is helpful: by bringing people who are outside formal decision-making processes into a new relationship with power-holders and by developing people's capacity to shape their future i.e. a generative or productive type of power that creates new possibilities and actions without domination. Both changes can be seen to have occurred in the seedling system case; both seem to have been catalysed by the IPs' activities.

In summary, this study appears to support both the 'intervention' and the 'power' hypothesis as causal explanations of innovation. More exactly, it suggests that the two are inter-dependent and co-causal.

According to Homann-Kee Tui et al. (2013), the development of innovative capacity occurs when people involved in an enterprise or domain are enabled to shape their own future by taking advantage of opportunities and are empowered to deal with changing situations. Their own experience suggests that the recognisable features of innovation capacity include self-organising, co-learning of new skills, changing mind-sets, accepting other people's contributions, developing a more holistic view of the enterprise, domain and context, creating new ideas by blending indigenous and expert understanding, being proactive, and looking to the future. This study records a number of these elements, of which the following seem with hindsight to have been especially important:

- the investigations prior to establishing the IPs, which began to reduce the tensions in the corrupted seed system and identify individuals who were looking for constructive ways forward. In the communes, the RA and PhD student became known as trustworthy individuals;

- the time taken to help IP members understand their roles as agents of change, based on informed understanding and a co-evolving (rather than pre-set) pathway of change;

- the change in inter-personal and inter-organisational power relations required for change in technical practices. 
Table 3. Analysis of inter-organisational power relationships.

Tableau 3. Analyse des relations de pouvoir entre organisations. Situation avant le démarrage de la plate-forme d'innovation et situation mi2014.

Situation before IPs began their work

Mutual dependency

Researchers/ extension agents

Co-existence/cooperation

Individuals who became IP members, traditional authorities, local government

Synergy

Individuals who became IP members and small-scale processors
One-sided dependency

Nursery holders on researchers and extension agents

Competition

Among nursery holders and between larger and smaller growers

\section{Antagonism}

Between cheated farmers and those who were corrupting seedling supply

Situation mid 2014

Mutual dependency

Researchers/extension agents/growers

Co-existence/cooperation

IP members, traditional authorities, local government

Synergy

IP members, small-scale farmers \& processors, micro-finance agencies, input dealers
One-sided dependency

Processors on credit agencies

Competition

Among authorised and unauthorised nurseries

Antagonism

CRA-PP's certification agents and unauthorised nurserymen
Source: IP members' analyses of TGPI data.

These became encoded in new formal and informal norms, regulations and rules, backed by formal powers to sanction deviant behaviours;

- the governance of the seed system has become a shared and more transparent business.

\section{Conclusion}

This study of institutional changes in the oil palm seed system in Benin makes a plausible case that these can be attributed in large part to the interventions of the two IPs but also to the additional research studies and facilitation services supported by the CoS-SIS programme and latent champions of change already situated in the context. A niche for experimentation was opened up that gave rise to new national responsibilities for the research centre, national research institute for perennial crops, and led to the inclusion of the institutional development of the oil palm seed system in the new 5-year Agricultural Development Plan.

The efforts reported here achieved considerably more than former smallholder oil palm development projects. It is concluded that the innovative aspects of this approach were the preliminary efforts made to understand the situation, the composition of the IPs on the basis of individuals' enthusiasm (rather than organisational representatives), the care taken to build trust in and the legitimacy of the IPs through shared experimentation and co-learning, the careful probing of ways forward that was accompanied by a stream of new evidence about what was working, and what was not, and hard, reflective discussion of the next steps in the light of the evidence. Although the counter-factual cannot be proved there is a strong, reasonable presumption that none of this would have happened without the 'institutional innovation' of the IPs.
Acknowledgements. We would like to thank the Ministry of Development Cooperation in The Netherlands for funding the CoS-SIS programme, and the farmers, nursery holders, NGOs, state cooperatives, extension services, and staff of the research centre (CRA-PP) for their cooperation. The support throughout by the Programme Management Team is gratefully acknowledged. We thank Dr George Essegbey and the late Dr Owuraku Sakyi-Dawson for their comments on earlier versions of this manuscript.

\section{References}

Akpo E, Vissoh VP, Tossou CR, Crane T, Kossou KD, Richards P, et al. 2012. A participatory diagnostic study of oil palm (Elaeis guineesis) seed system in Benin. NJAS-Wageningen Journal of Life Sciences 60-63:15-27. 10.1016/j.njas.2012.06.003.

Akpo E, Crane T, Stomph J, Tossou CR, Kossou KD, Vissoh VP, et al. 2014a. Social institutional dynamics of seed system reliability: the case of oil palm in Benin. International Journal of Agricultural Sustainability 12(3): 214-232. 10.1080/14735903.909634.

Akpo E, Stomph J, Kossou KD, Omore OA, Struik CP. 2014b. Effects of nursery management practices on morphological quality attributes of tree seedlings at planting: the case of oil palm (Elaeis guineensis). Forest Ecology and Management 324: 28-36. 10.1016/ j.forco.2014.03.045.

Akpo E, Stomph J, Kossou KD, Struik CP. 2014c. Growth dynamics of tree nursery seedlings: The case of oil palm. Scientia Horticulturae 175: 251-257. 10.1016/j.scienta.2014.06.020.

Akpo E, Crane T, Vissoh VP, Tossou CR. 2014d. Co-production of knowledge in multi-stakeholder processes: analysing joint experimentation as social learningThe Journal of Agricultural Education and Extension 21(4): 369-388. 10.1080/1389224X.2014.930201.

Avelino F, Rotmans J. 2009. Power in transition: an interdisciplinary framework to study power in relation to structural change. European Journal of Social Theory 12(4): 543-569. 
Faletti TG. 2006. Theory-guided process-tracing in comparative politics: something old, something new. American Political Science Association Comparative Politics Newsletter 17(1): 9-14.

Fuchs D, Graab K. 2011. Material power and normative conflict in global and local agrifood governance: The lessons of 'Golden Rice' in India. Food Policy 36: 729-735.

George A, Bennett A. 2005. Belfer Centre Studies in International security. Cambridge (Mass.): The MIT Press.

GIZ. 2011. Handbook for facilitation of multi-stakeholder processes. Bonn and Eschborn: Deutsche Gesellschaft für Internationale Zusammenarbeit.

Homann-Kee Tui S, Adekunle A, Lundy M, Tucker J, Birachi E, Schut $\mathrm{M}$, et al. 2013. What are innovation platforms? Innovation Platforms Practice Brief 1. Nairobi, Kenya: ILRI. http://hdl. handle.net/10568/34157 or https://clippings.ilri.org/2014/02/03/ ipbrief1/.

Hounkonnou D, Kossou D, Kuyper WT, Leeuwis C, Nederlof ES, Röling N, et al. 2012. An innovation systems approach to institutional change: Stakeholder development in West Africa. Agricultural Systems 108: 74-83.

Jiggins J, Essegbey G, Klerkx L, van Pasasen A, Pyburn R, Tossou R. 2016. The uses of research: action researching in and across nine agro-environment domains. The experience of the Convergence of Sciences-Strengthening Innovation Systems Program in Benin, Ghana and Mali. Chapter 8. In: Francis J, Mytelka L, van Huis A, Röling N (eds.). 2016. Innovation Systems: Towards Effective Strategies in Support of Smallholder Farmers. Technical Centre for Agricultural and Rural Cooperation (CTA) and Wageningen University and Research Centre (WUR)/Convergence of Sciences-Strengthening Innovation Systems (CoS-SIS), Wageningen, in press.
Klerkx L, Aarts N. 2013. The interaction of multiple champions in orchestrating innovation networks: conflicts and complementarities. Technovation 33: 193-210.

Klerkx L, Adjei-Nsiah S, Adu-Acheampong R, Saïdou A, Zannou E, Soumano L, et al. 2013. Looking at agricultural innovation platforms through an innovation champion lens. An analysis of three cases in West Africa. Oulook on Agriculture 42(3): 185-192. 10.5367/oa.2013.0137.

Nederlof ES, Pyburn R. 2012. One finger cannot lift a rock: Facilitating innovation platforms to trigger institutional change in West Africa. Amsterdam: KIT Publishers. www.kit.nl.

Rowlands J. 1997. Questioning empowerment: working with women in Honduras. Oxford: Oxfam Publications.

Spielman D, Ekboir J, Davis K. 2009. Developing the art and science of innovation systems enquiry: alternative tools and methods and applications to Sub-Saharan African agriculture. In: Sanginga P, Waters-Bayer A, Kaaria S, Njuki J, Wettasinha C. (eds.), Innovation Africa: enriching farmers' livelihoods. London: Earthscan, pp. 72-88.

Triomphe B, Floquet A, Kamau G, Letty B, Vodouhè SD, Ng'ang'a $\mathrm{T}$, et al. 2013. What does an inventory of recent innovations experiences tell us about agricultural innovation in Africa? The Journal of Agricultural Education and Extension 19: 311-324. 10.1080/1389224X.2013.782181.

van Paassen A, Klerkx L, Adu-Acheampong R, Adjei-Nsiah S, Ouologuem B, Zannou E, et al. 2013. Choice making in facilitating of agricultural innovation platforms in different contexts in West Africa: experiences from Benin, Ghana and Mali. Knowledge Management for Development Journal 9(3): 79-94. http:/journal. km4dev.org/. ISSN (Online): 0030-7270.

Vissoh VP, Adjei-Nsiah S, van Huis A, Röling N. 2010. Opportunities for Oil Palm development in Benin and Ghana: Institutional conditions for technological change. Aspects of Applied Biology 96: 1-8.

Cite this article as: Vissoh PV, Tossou RC, Akpo E, Kossou D, Jiggins J. 2017. Innovating a system for producing and distributing hybrid oil palm seedlings to smallholder farmers in Benin. Cah. Agric. 26: 15002. 